\title{
Escherichia coli as a Multifaceted Pathogenic and Versatile Bacterium
}

\author{
Vânia Santos Braz ${ }^{\dagger}$, Karine Melchior and Cristiano Gallina Moreira ${ }^{\star \dagger}$ \\ Department of Biological Sciences, School of Pharmaceutical Sciences, São Paulo State University (UNESP), \\ Araraquara, Brazil
}

Genetic plasticity promotes evolution and a vast diversity in Escherichia coli varying from avirulent to highly pathogenic strains, including the emergence of virulent hybrid microorganism. This ability also contributes to the emergence of antimicrobial resistance. These hybrid pathogenic E. coli (HyPEC) are emergent threats, such as

OPEN ACCESS

Edited by:

Mauricio J. Farfan,

University of Chile, Chile

Reviewed by:

Sanjana Mukherjee,

United States Food and Drug

Administration, United States

Cecilia Shirley Toro,

University of Chile, Chile

*Correspondence:

Cristiano Gallina Moreira

cg.moreira@unesp.br

tORCID:

Vânia Santos Braz

orcid.org/0000-0002-1389-1055

Cristiano Gallina Moreira

orcid.org/0000-0002-0689-4119

Specialty section:

This article was submitted to

Bacteria and Host,

a section of the journal

Frontiers in Cellular and

Infection Microbiology

Received: 02 April 2020

Accepted: 17 November 2020

Published: 21 December 2020

Citation:

Braz VS, Melchior K and Moreira CG (2020) Escherichia coli as a Multifaceted Pathogenic

and Versatile Bacterium.

Front. Cell. Infect. Microbiol. 10:548492.

doi: 10.3389/fcimb.2020.548492
O104:H4 from the European outbreak in 2011, aggregative adherent bacteria with the potent Shiga-toxin. Here, we briefly revisited the details of these $E$. coli classic and hybrid pathogens, the increase in antimicrobial resistance in the context of a genetically empowered multifaceted and versatile bug and the growing need to advance alternative therapies to fight these infections.

Keywords: treatment, genetic mobility, pathogenesis, Escherichia, multiresistant

\section{INTRODUCTION}

Escherichia coli (or E. coli) is a Gram-negative versatile bacterium, easily found and amenable to natural and random genetic alteration. There is a vast collection of sequenced $E$. coli genomes which exhibit different sizes and genomic diversity among commensal and pathogens, indicating a great assortment within the same bacterial species. They comprise of non-pathogenic bacteria that may act as commensals and belong to the normal intestinal microbiota of humans and many animals. There are also pathogenic variants, divided as diarrheagenic and extraintestinal pathogens, with different pathotypes and various natural hybrid strains (Tables 1 and 2). These variants can be facultative or obligate pathogens. The facultative bacteria are part of the intestinal tract and may act as opportunistic pathogens when outside of their natural habitat, causing various types of extraintestinal infections. On the other hand, intestinal obligate pathogenic variants cause infections in distinct conditions, from moderate diarrhea to more threatening cases, as lethal outcome (Kaper et al., 2004; Köhler and Dobrindt, 2011).

E. coli pangenome studies indicate enormous capacity to evolve by gene acquisition and genetic modification. Besides, these genomes have a mosaic-like structure consisting of a core genome, encoding essential cellular functions, and an accessory genome with flexible strain-specific sequences. Thus, $E$. coli is a model well established for studying the interdependence of genome architecture and the lifestyle of bacteria (Touchon et al., 2009; Dobrindt et al., 2010).

Based on virulence factors in E. coli genomes and phenotypic traits, the human pathotypes of diarrheagenic E. coli (DEC) are differentiated from non-pathogenic E. coli and extraintestinal pathogenic E. coli (ExPEC). The ExPEC are classified as uropathogenic E. coli (UPEC), sepsiscausing E. coli (SEPEC) and neonatal meningitis-associated E. coli (NMEC) (Kaper et al., 2004). Recent pathogenomics and phenotypic classification have revisited the DEC group as nine distinct 
TABLE 1 | Classic E. coli pathotypes main features: extraintestinal (EXPEC) and diarrheagenic (DEC).

\begin{tabular}{|c|c|c|c|c|c|}
\hline $\begin{array}{l}\text { E. coli Pathotype } \\
\text { (DEC and ExPEC) }\end{array}$ & Main virulence traits & $\begin{array}{c}\text { Clinical } \\
\text { manifestation }\end{array}$ & $\begin{array}{l}\text { Antimicrobial resistance } \\
\text { (AMR) commonly found }\end{array}$ & $\begin{array}{l}\text { Mobile genetic } \\
\text { resistance } \\
\text { determinants }\end{array}$ & References \\
\hline $\begin{array}{l}\text { Shiga toxin- } \\
\text { producing (STEC) }\end{array}$ & Shiga-toxin & $\begin{array}{l}\text { Not associated } \\
\text { with human } \\
\text { diseases }\end{array}$ & $\begin{array}{l}\text { Streptomycin, Ampicillin, } \\
\text { Tetracyclin and } \\
\text { sulphonamides }\end{array}$ & ND & $\begin{array}{l}\text { Jerse et al., 1990; } \\
\text { Kaper et al., 2004; } \\
\text { Day et al., } 2017\end{array}$ \\
\hline $\begin{array}{l}\text { Enterohemorrhagic } \\
\text { (EHEC) }\end{array}$ & $\begin{array}{l}\text { EscF, EscC, EspA, EspB, EspD, Intimin, Tir, and } \\
\text { Shiga-toxin }\end{array}$ & $\begin{array}{l}\text { Foodborne } \\
\text { Bloody diarrhea } \\
\text { and HUS }\end{array}$ & $\begin{array}{l}\text { Streptomycin, Ampicillin, } \\
\text { Tetracyclin and } \\
\text { sulphonamides }\end{array}$ & $\begin{array}{l}\text { Resistance } \\
\text { plasmid-mediated } \\
\text { (as p0157, } \\
\text { p0111-CRL115, } \\
\text { p026-CRL125, } \\
\text { p0145-13514) }\end{array}$ & $\begin{array}{l}\text { Knutton et al., 1989; } \\
\text { Mellies et al., 1999; } \\
\text { Kaper et al., 2004; } \\
\text { Garmendia et al., } \\
\text { 2005; Day et al., } \\
2017\end{array}$ \\
\hline $\begin{array}{l}\text { Enteropathogenic } \\
\text { (EPEC) }\end{array}$ & $\begin{array}{l}\text { EscF, EscC, EspA, EspB, EspD, Intimin, Tir, EAF } \\
\text { plasmid (tEPEC) and Bfp (tEPEC) }\end{array}$ & Watery diarrhea & $\begin{array}{l}\text { Streptomycin, Ampicillin, } \\
\text { Tetracyclin, Trimethoprim and } \\
\text { Sulfamethoxazole }\end{array}$ & $\begin{array}{l}\text { Resistance } \\
\text { plasmid-mediated } \\
\text { (as pEAF, MB80, } \\
\text { pB171_90, } \\
\text { pED208) }\end{array}$ & $\begin{array}{l}\text { Tobe et al., 1999; } \\
\text { Trabulsi et al., 2002; } \\
\text { Kaper et al., 2004; } \\
\text { Ingle et al., } 2018\end{array}$ \\
\hline $\begin{array}{l}\text { Enteroaggregative } \\
\text { (EAEC) }\end{array}$ & $\begin{array}{l}\text { pAA plasmid, aggregated fimbriae adhesion (AAF), } \\
\text { AggR regulator and dispersin }\end{array}$ & $\begin{array}{l}\text { Acute and } \\
\text { chronic } \\
\text { diarrhea }\end{array}$ & $\begin{array}{l}\text { Ampicillin, Trimethoprim, } \\
\text { Sulfamethoxazole, Nalidixic } \\
\text { acid, and ciprofloxacin }\end{array}$ & $\begin{array}{l}\text { Resistance } \\
\text { plasmid-mediated } \\
\text { (as pAA), } \\
\text { chromosomal } \\
\text { gyrB and parC } \\
\text { mutations }\end{array}$ & $\begin{array}{l}\text { Regua-Mangia et al., } \\
\text { 2009; Aslani et al., } \\
\text { 2011; Gomes et al., } \\
\text { 2016; Pawłowska } \\
\text { and } \\
\text { Sobieszczańska, } \\
\text { 2017; Chattaway } \\
\text { et al., } 2017\end{array}$ \\
\hline $\begin{array}{l}\text { Enteroinvasive } \\
\text { (EIEC) }\end{array}$ & Plasmid pINV and invasins & $\begin{array}{l}\text { Bacillary } \\
\text { Dysentery }\end{array}$ & $\begin{array}{l}\text { Carbapenem, fosfomycin- } \\
\text { trometanol, nitrofurantoin, } \\
\text { chloramphenicol, } \beta \text {-lactams, } \\
\text { nalidixic acid, ampicillin and } \\
\text { fluoroquinolones }\end{array}$ & $\begin{array}{l}\text { Resistance } \\
\text { plasmid- } \\
\text { mediated, } \\
\text { chromosomal } \\
\text { gyrB and parC } \\
\text { mutations }\end{array}$ & $\begin{array}{l}\text { Kaper et al., 2004; } \\
\text { Baylis et al., 2006; } \\
\text { Gomes et al., 2016; } \\
\text { Pawłowska and } \\
\text { Sobieszczańska, } \\
2017\end{array}$ \\
\hline $\begin{array}{l}\text { Enterotoxigenic } \\
\text { (ETEC) }\end{array}$ & Thermostable (ST) and thermolabile (LT) enterotoxins & $\begin{array}{l}\text { Watery } \\
\text { diarrhea, } \\
\text { known as } \\
\text { traveler's } \\
\text { diarrhea }\end{array}$ & $\begin{array}{l}\text { Ampicillin, sulfamethoxazole, } \\
\text { tetracycline and azithromycin }\end{array}$ & $\begin{array}{l}\text { Resistance } \\
\text { plasmid-mediated } \\
\text { (distinct Inc type } \\
\text { conjugative } \\
\text { plasmids) }\end{array}$ & $\begin{array}{l}\text { Kaper et al., 2004; } \\
\text { Medina et al., 2015; } \\
\text { Gomes et al., 2016; } \\
\text { Pawłowska and } \\
\text { Sobieszczańska, } \\
2017\end{array}$ \\
\hline $\begin{array}{l}\text { Diffusely-adhering } \\
\text { (DAEC) }\end{array}$ & Afa/Dr adhesins & $\begin{array}{l}\text { Acute diarrhea } \\
\text { to } \\
\text { assypmtomatic } \\
\text { cases }\end{array}$ & $\begin{array}{l}\text { Ampicillin, Trimethoprim, } \\
\text { Sulfamethoxazole, } \\
\text { Fosfomycin, piperacillin, } \\
\text { tetracycline, ciprofloxacin, co- } \\
\text { trimoxazole, nitrofurantoin, } \\
\text { oxacillin, bactericin, cloxacillin, } \\
\text { chloramphenicol, and nalidixic } \\
\text { acid }\end{array}$ & $\begin{array}{l}\text { Resistance } \\
\text { plasmid- } \\
\text { mediated, } \\
\text { chromosomal } \\
\text { gyrB and parC } \\
\text { mutations }\end{array}$ & $\begin{array}{l}\text { Kaper et al., 2004; } \\
\text { Nash et al., 2010; } \\
\text { Servin, 2014; } \\
\text { Gomes et al., } 2016\end{array}$ \\
\hline $\begin{array}{l}\text { Adherent-invasive } \\
\text { (AIEC) }\end{array}$ & $\begin{array}{l}\text { type VI secretion system, type I pili, long polar } \\
\text { fimbriae }\end{array}$ & $\begin{array}{l}\text { Chronic gut } \\
\text { inflammation } \\
\text { and Crohn's } \\
\text { disease }\end{array}$ & Ampicillin and ciprofloxacin & $\begin{array}{l}\text { Resistance } \\
\text { plasmid- } \\
\text { mediated, } \\
\text { chromosomal } \\
\text { gyrB and parC } \\
\text { mutations }\end{array}$ & $\begin{array}{l}\text { Kaper et al., 2004; } \\
\text { Nash et al., 2010; } \\
\text { Barrios-Villa et al., } \\
2018\end{array}$ \\
\hline $\begin{array}{l}\text { Cell-detaching } \\
\text { (CDEC) }\end{array}$ & $\begin{array}{l}\text { K-hemolysin, pyelonephritis-associated pili and } \\
\text { cytotoxic necrotizing factor } 1 \text { (CNF1) }\end{array}$ & $\begin{array}{l}\text { Diarrhea in } \\
\text { infants, cell } \\
\text { detaching, and } \\
\text { inked to Crohn' } \\
\text { s disease } \\
\text { cases }\end{array}$ & $\begin{array}{l}\text { Amoxicillin-clavulanic acid, } \\
\text { ampicillin, mezlocillin, } \\
\text { piperacillin, tetracycline, } \\
\text { trimethoprim, trimethoprim- } \\
\text { sulfamethoxazole, } \\
\text { spectinomycin, streptomycin } \\
\text { and sulfonamide }\end{array}$ & $\begin{array}{l}\text { Resistance } \\
\text { plasmid- } \\
\text { mediated, } \\
\text { integrons }\end{array}$ & $\begin{array}{l}\text { Elliott et al., 1998; } \\
\text { Fábrega et al., 2002; } \\
\text { Okeke et al., 2002; } \\
\text { Kaper et al., 2004; } \\
\text { Rakitina et al., 2017 }\end{array}$ \\
\hline $\begin{array}{l}\text { Uropathogenic } \\
\text { (UPEC) }\end{array}$ & $\begin{array}{l}\text { P fimbriae, certain other mannose-resistant adhesins, } \\
\text { and type } 1 \text { fimbriae, } \mathrm{K} \text { capsule, Hemolysin, } \\
\text { Aerobactin }\end{array}$ & $\begin{array}{l}\text { Urinary and } \\
\text { Bloodstream } \\
\text { infections }\end{array}$ & $\begin{array}{l}\text { Fluoroquinolone, } \\
\text { aminoglycosides, } \\
\text { trimethoprim- } \\
\text { sulfamethoxazole and } \\
\text { carbapenems }\end{array}$ & $\begin{array}{l}\text { Resistance } \\
\text { plasmid- } \\
\text { mediated, } \\
\text { transposons, } \\
\text { integrons, } \\
\text { chromosomal }\end{array}$ & $\begin{array}{l}\text { Kaper et al., 2004; } \\
\text { Mobley et al., 2009; } \\
\text { Petty et al., } 2014\end{array}$ \\
\hline
\end{tabular}

(Continued) 
TABLE 1 | Continued

\begin{tabular}{|c|c|c|c|c|c|}
\hline $\begin{array}{l}\text { E. coli Pathotype } \\
\text { (DEC and ExPEC) }\end{array}$ & Main virulence traits & $\begin{array}{l}\text { Clinical } \\
\text { manifestation }\end{array}$ & $\begin{array}{l}\text { Antimicrobial resistance } \\
\text { (AMR) commonly found }\end{array}$ & $\begin{array}{l}\text { Mobile genetic } \\
\text { resistance } \\
\text { determinants }\end{array}$ & References \\
\hline & & & & $\begin{array}{l}\text { gyrA, gyrB, parE, } \\
\text { parC and marA } \\
\text { mutations }\end{array}$ & \\
\hline $\begin{array}{l}\text { Sepsis-causing } \\
\text { (SEPEC) }\end{array}$ & $\begin{array}{l}\text { Type } 1 \text {, } \mathrm{P} \text {, and S fimbriae, } \mathrm{K} \text { capsule } \mathrm{K} 1 / \mathrm{K} 5 \text {, } \\
\text { hemolysin, aerobactin, yersiniabactin, salmochelin, } \\
\text { CNF1, secreted autotransporter toxin, serum } \\
\text { resistance, and colicin } \mathrm{V}\end{array}$ & $\begin{array}{l}\text { Bacteremia and } \\
\text { sepsis }\end{array}$ & Carbapenems & $\begin{array}{l}\text { Resistance } \\
\text { plasmid- } \\
\text { mediated, } \\
\text { integrons }\end{array}$ & $\begin{array}{l}\text { Kaper et al., 2004; } \\
\text { Mokady et al., 2005; } \\
\text { Nagarjuna et al., } \\
2018\end{array}$ \\
\hline $\begin{array}{l}\text { Neonatal } \\
\text { meningitis- } \\
\text { associated (NMEC) }\end{array}$ & $\begin{array}{l}\text { ompTp, hlyF, cvaC, ets } A, c v a A \text {, etsB, cvaB, iss, iut } A \text {, } \\
\text { and tsh }\end{array}$ & $\begin{array}{l}\text { Meningitis, and } \\
\text { bacteremia in } \\
\text { neonates }\end{array}$ & $\begin{array}{l}\text { Streptomycin sulfisoxazole, } \\
\text { ampicillin, tetracycline, } \\
\text { chloramphenicol, kanamycin } \\
\text { and trimethoprim- } \\
\text { sulfamethoxazole }\end{array}$ & $\begin{array}{l}\text { Resistance } \\
\text { plasmid-mediated }\end{array}$ & $\begin{array}{l}\text { Korhonen et al., } \\
\text { 1985; Kaper et al., } \\
2004 \text {; Logue et al., } \\
2012\end{array}$ \\
\hline
\end{tabular}

ND, non-described.

pathotypes, proposed by their differential features and the essential virulence genes defining each subgroup, such as Shiga toxinproducing E. coli (STEC), enterohemorrhagic E. coli (EHEC), enteropathogenic E. coli (EPEC), enterotoxigenic E. coli (ETEC), enteroinvasive E. coli (EIEC), enteroaggregative E. coli (EAEC), diffusely-adhering E. coli (DAEC), adherent-invasive E. coli (AIEC), and cell-detaching E. coli (CDEC) (Kaper et al., 2004; Pawłowska and Sobieszczańska, 2017) (Table 1).

Herein, we briefly describe the diversity of these classic and novel emerging $E$. coli pathotypes and their genetic plasticity in a multifaceted organism. The mobile genetic elements are responsible for the appearance of novel hybrid strains with distinct assortment of virulence and antimicrobial resistance traits, bringing up the urgent need to reconsider the forms of treatment for these infections.

\section{TYPES OF E. COLI: MANY FLAVORS WITHIN A SINGLE BACTERIAL SPECIES}

E. coli is one of the most genetically versatile microorganisms and is able to colonize and persist in several niches, both in the environment or in hosts. Commensal E. coli strains colonize the gastrointestinal tract of humans a few hours after birth, resulting in a symbiotic relationship between the microbiota and its host (Ducarmon et al., 2019). However, the mechanisms by which $E$. coli ensures this efficient symbiosis is not well known. It could be related to its high ability to use nutrients in the colon (Fabich et al., 2008; Ducarmon et al., 2019). Several studies have shown that competition for nutrients between microbiota and pathogens limits the colonization of the pathogens, leading to fierce competition among these microorganisms (Lustri et al., 2017).

Occasionally, pathogenic E. coli cannot be distinguished from commensal E. coli, only based on specific virulence factors, as some previously described in ExPEC strains (Köhler and Dobrindt, 2011). However, this scenario is changing due to sophistication and availability of molecular typing methodologies. New computational approaches bring countless important information about hostpathogen relationships, reservoir, clinical diagnoses, and novel ExPEC transmission pathways (Johnson and Russo, 2018). Often, virulence genes are located in transmissible genetic elements such as genomic islands, bacteriophages, insertion sequences (ISs), integrons, plasmids, and transposons; hence, they can be easily exchanged among different bacteria (Hacker et al., 2003; Dobrindt et al., 2010). They also carry multiple antibiotic resistance genes that have been under strong selective pressure as consequence of the extensive use of antibiotics (Brzuszkiewicz et al., 2009).

Common genetic changes in E. coli genomes ensure high diversity due to the gain and loss of genes through genetic modification events. There are many strains of ExPEC that normally colonize the gut asymptomatically, as members of the intestinal microbiota. Nonetheless, only a subset of ExPEC as UPEC, SEPEC and NMEC are responsible for the vast majority of infections such as urinary tract infections, sepsis, and meningitis (Kaper et al., 2004). There is a great variety of virulence factors in ExPEC strains, such as adhesins (fimbrial and non-fimbrial), siderophores, toxins, invasins, the ability to survive in serum, among others. Moreover, many of these virulence factors may occur combined within the same strain and act synergistically. Despite extra factors, the septic strains always possess at least an adherence system, an iron uptake system and genes for serum survival (Biran and Ron, 2018; Johnson and Russo, 2018) (Table 1).

The genetic evolution in E. coli pathogenesis employs horizontal transfer mechanisms within same and across similar species. Therefore, the IS, transposons and integrons may facilitate novel rearrangements within the genome, such as duplication and suppression of genes and also capture of new genes. This genetic material transit can result in greater flexibility concerning various features, such as the transition of pathogenic bacteria between humans and animals, resistance to antimicrobials, appearance of emerging pathogens due to the gain of virulence genes, increased pathogenicity, among other features (Frost et al., 2005; Brigulla and Wackernagel, 2010; Dobrindt et al., 2010; Jackson et al., 2011; Sheppard et al., 2018). All these conditions may contribute to the virulence of these bacteria, like the bacteriophage importance in the pathogenesis. The horizontal transfer between different strains favors the emergence of new pathogenic strains with discrepancies in the bacteriophage repertoire affecting directly their virulence (Manning et al., 2008; Ogura et al., 2009; Dobrindt et al., 2010; Jackson et al., 2011). 
TABLE 2 | Hybrid pathogenic (HyPEC) main features described.

\begin{tabular}{|c|c|c|c|c|c|}
\hline HyPEC & $\begin{array}{c}\text { Main } \\
\text { features }\end{array}$ & $\begin{array}{l}\text { Hybrid virulence traits } \\
\text { identified }\end{array}$ & $\begin{array}{c}\text { Clinical manifes- } \\
\text { tation }\end{array}$ & $\begin{array}{l}\text { Antimicrobial } \\
\text { resistance (AMR) } \\
\text { described }\end{array}$ & References \\
\hline $\begin{array}{l}\text { O1O4:H4 } \\
\text { EAEC/ } \\
\text { STEC }\end{array}$ & $\begin{array}{l}\text { Hybrid EAEC } \\
\text { with STEC }\end{array}$ & $\begin{array}{l}\text { Aggregative typical fimbriae, } \\
\text { Shiga toxin }\end{array}$ & Diarrhea, HUS & Quinolones and $\beta$-lactams & $\begin{array}{l}\text { Bielaszewska et al., 2011; Rasko et al., 2011; Muniesa } \\
\text { et al., 2012; Navarro-Garcia, 2014; Ribeiro et al., } 2019\end{array}$ \\
\hline $\begin{array}{l}\text { O8O:H2 } \\
\text { STEC/ } \\
\text { EXPEC }\end{array}$ & $\begin{array}{l}\text { Hybrid STEC } \\
\text { with ExPEC }\end{array}$ & $\begin{array}{l}\text { Intimin, Shiga toxin and pS88- } \\
\text { like plasmid }\end{array}$ & $\begin{array}{l}\text { HUS, } \\
\text { Bacteremia }\end{array}$ & $\beta$-lactams & Peigne et al., 2009; Mariani-Kurkdjian et al., 2014 \\
\hline $\begin{array}{l}\text { O2:H6 } \\
\text { STEC/ } \\
\text { UPEC }\end{array}$ & $\begin{array}{l}\text { Hybrid STEC } \\
\text { with UPEC }\end{array}$ & $\alpha$-hlyA, cnf1 and clb genes & $\begin{array}{l}\text { Diarrhea, } \\
\text { Urinary tract } \\
\text { infections, HUS }\end{array}$ & ND & Bielaszewska et al., 2014 \\
\hline $\begin{array}{l}\text { ST131 } \\
\text { UPEC/ } \\
\text { EAEC }\end{array}$ & $\begin{array}{l}\text { Hybrid } \\
\text { ExPEC with } \\
\text { EAEC }\end{array}$ & pAA plasmid & $\begin{array}{l}\text { Urinary infections, } \\
\text { Bloodstream } \\
\text { infections and } \\
\text { Diarrhea }\end{array}$ & $\beta$-lactams & Boll et al., 2018 \\
\hline $\begin{array}{l}\text { EPEC/ } \\
\text { ETEC }\end{array}$ & $\begin{array}{l}\text { Hybrid EPEC } \\
\text { and ETEC }\end{array}$ & $\begin{array}{l}\text { Intimin, LEE island, ST and LT } \\
\text { toxin }\end{array}$ & $\begin{array}{l}\text { Diarrhea, } \\
\text { Mild fever and } \\
\text { cough }\end{array}$ & $\begin{array}{l}\beta \text {-lactams, SUT, and } \\
\text { quinolones }\end{array}$ & Dutta et al., 2015 \\
\hline $\begin{array}{l}\text { STEC/ } \\
\text { ETEC }\end{array}$ & $\begin{array}{l}\text { Hybrid STEC } \\
\text { and ETEC }\end{array}$ & $\begin{array}{l}\text { Intimin, Shiga toxin (Stx2) and } \\
\text { LT toxin }\end{array}$ & $\begin{array}{l}\text { Acute diarrhea } \\
\text { and HUS }\end{array}$ & ND & Lindstedt et al., 2018 \\
\hline $\begin{array}{l}\text { O137:H6 } \\
\text { (ST2678) } \\
\text { EPEC/ } \\
\text { STEC }\end{array}$ & $\begin{array}{l}\text { Hybrid EPEC } \\
\text { and STEC }\end{array}$ & $\begin{array}{l}\text { Intimin, BFP, Shiga toxin } \\
\text { (Stx2) and AIDA-I } \\
\text { autotransporter }\end{array}$ & Diarrhea and HUS & ND & Gioia-Di Chiacchio et al., 2018 \\
\hline $\begin{array}{l}\text { STEC/ } \\
\text { ETEC }\end{array}$ & $\begin{array}{l}\text { Hybrid STEC } \\
\text { and ETEC }\end{array}$ & $\begin{array}{l}\text { Intimin, Shiga toxin, ST and } \\
\text { LT toxins }\end{array}$ & $\begin{array}{l}\text { Acute diarrhea } \\
\text { and HUS }\end{array}$ & ND & Nyholm et al., 2015 \\
\hline $\begin{array}{l}\text { EPEC/ } \\
\text { ETEC }\end{array}$ & $\begin{array}{l}\text { Hybrid EPEC } \\
\text { and ETEC }\end{array}$ & Intimin, BFP, ST and LT toxins & $\begin{array}{l}\text { Diarrhea, } \\
\text { Mild fever and } \\
\text { cough }\end{array}$ & ND & Hazen et al., 2017 \\
\hline
\end{tabular}

HyPEC, Hybrid Pathogenic E. coli; HUS, Hemolytic Uremic Syndrome; ND, non-described; SUT, Trimethoprim-sulfamethoxazole.

The co-evolution of bacterial genomes with plasmids, besides potential genetic and phenotypic gain may impact cellular metabolism to ensure the maintenance and stability of the plasmid (Jackson et al., 2011). Many ExPEC virulence genes are encoded within plasmids, often belonging to the ColV family, which encodes colicin, serum survival factors and iron uptake systems (Biran and Ron, 2018). Similarly, intestinal pathogens carry a variety of types of plasmids, associated with virulence, majorly belonging to the incompatibility group IncF, which has transfer functions (Carattoli, 2009). There are virulence plasmids essential for some pathotypes of E. coli, such as pINV and pAA, respectively, in EIEC and EAEC, according to each own group features (Kaper et al., 2004).

Although, all ExPEC and DEC pathotypes are not enough to fully classify all pathogenic $E$. coli strains, since these bacteria are so variable, allowing constant appearance of distinct hybridformed strains within this dynamic bacterial species. The carriage of virulence genes essential to the pathogenesis of each pathotype and the ability to adapt to different conditions allow the emergence of hybrid pathogenic E. coli (HyPEC).

\section{GENETIC PLASTICITY AND EMERGENT E. COLI PATHOGEN: HYPEC}

E. coli has an astonishing facility to amend very well, replicate and disseminate. These features allowed the advent of novel HyPEC. Acquired virulence genes and novel functions appear from mutation, recombination and other genetic changes. All these genetic differences have increased the occurrence of novel hybrid and antimicrobial resistance among DEC and ExPEC (Dobrindt et al., 2003; Bielaszewska et al., 2007; Khan et al., 2018).

Recently, a HyPEC strain received widespread attention after an outbreak of foodborne bloody diarrhea and hemorrhagic uremic syndrome (HUS) in Germany. This outbreak of E. coli O1O4:H4 was associated with consumption of raw fenugreek sprouts, as a hybrid EAEC strain with STEC features, like Shiga toxin presence. This HyPEC was quickly sequenced and unraveled its intricate nature, but even with a quick response and identification it was not enough to avoid 3,842 hospitalizations with many fatalities in Europe and North Africa (Bielaszewska et al., 2011; Rasko et al., 2011). Emerging processes are responsible for the HyPEC occurrences. Herein, the combined enteroaggregative features in a rare serotype was responsible to high attachment to cells and a biofilm formation (Navarro-Garcia, 2014; Ribeiro et al., 2019). Moreover, this strain has gained stx2 gene lambdoid phage integrated in the genome, thus it may release the Shiga-toxin. These features have increased HUS occurrence during the outbreak on this HyPEC when compared to STEC (Muniesa et al., 2012).

Many distinct genetic hybrid examples are reported in E. coli, such as STEC/ExPEC O80:H2 serotype, which caused HUS and bacteremia due the presence of stx2 and eae genes from STECs and pS88-like plasmid, described in meningitis, urosepsis and avian pathogenic strains of ExPEC (Peigne et al., 2009; Mariani- 
Kurkdjian et al., 2014). The STEC/UPEC strain O2:H6 serotype, a STEC with virulence genes as $\alpha$-hlyA, $c n f 1$, and $c l b$ from UPEC that have ability to cause diarrhea and urinary tract infections (Bielaszewska et al., 2014). The EPEC/ETEC strain has acquired the LEE island and encodes the LT toxin (Dutta et al., 2015). The broadly reported multidrug resistant E. coli ST131 is example of highly virulent ExPEC associated with urinary and bloodstream infections. It has also acquired enteroaggregative diarrheagenic phenotype due to pAA plasmid presence (Boll et al., 2018). Many others HyPEC are described as case report, but not fully characterized. Here, we have briefly sampled some of the acquired genes by these strains, their direct impact in virulence and their hybrid nature (Table 2). Comparable to these HyPEC, the coined terms hybrid- and hetero-pathogenic E. coli have been recently described as new combination of virulence factors among classic E. coli groups. Together, they show differences between typical and atypical subgroups within the EAEC and EPEC pathotypes and hybrids, such as EPEC/STEC, ExPEC/ EPEC and ExPEC/EAEC hybrids (Santos et al., 2020). Similar to our approach here, this study shows how this topic is critical in the field.

The high prevalence of classic pathogenic E. coli and appearance of HyPEC occur via similar genetic mechanisms, which also enable bacteria to resist the presence of distinct antimicrobials. Bacteria resistant to various classes of antibiotics are related to the complex combination of intrinsic and acquired resistance genes, which may act synergistically (Cag et al., 2016; Khan et al., 2018). Together that brings multiresistant bacteria, as an alarming factor reported worldwide in several bacterial species. WHO has prioritized studies on AMR bacteria, including Enterobacteriaceae, based on recent surveillance reports (WHO, 2018).

\section{EMERGING HYBRIDS AND ALTERNATIVE THERAPIES}

The complex combination of multidrug-resistant bacteria and emerging hybrid bacteria with intrinsic or acquired bacterial virulence factors disseminated by genetic mobility elements, the intense and inappropriate use of antibiotics have simultaneously favored the emergence of resistance to various antibiotics (Khan et al., 2018). That is a special challenge to these hybrid strains, since these HyPEC gathered virulence traits and acquired antibiotic resistance, together these points raise the importance to alternative treatments. These options are crucial to reduce the use of antibiotics and the consequent increase of antimicrobial resistance. Novel therapies are urgent to replace prophylactic and treatment with antibiotics by probiotics, prebiotics, enzymatic compounds, vaccines, monoclonal antibodies, phage therapy, antivirulence compounds, among other possibilities (Gadde et al., 2017).

Recently, different vaccine strategies have been used for pathogenic $E$. coli infection as an alternative to antibiotic therapy (Rojas-Lopez et al., 2018), including vaccines with attenuated toxins (McKenzie et al., 2007; Bitzan et al., 2009), attenuated bacterial cell (Calderon Toledo et al., 2011), individual components of virulence factors such as Shiga toxin (Liu et al., 2009), EspA or Intimin (Oliveira et al., 2012), small peptides (Zhang et al., 2011), DNA (García-Angulo et al., 2014) or polysaccharides (Ahmed et al., 2006; van den Dobbelsteen, 2016), as well detailed in the literature. Commercial vaccines have aimed the use to protect livestock, such as poultry, swine and bovine herds, against respectively to APEC, like Poulvac ${ }^{\circledR}$ E. coli, ETEC and EHEC infections (Sadeyen et al., 2015; Nesta and Pizza, 2018). Vaccines with a modern approach and technology still are a promising strategy to protect against emergent HyPECs infections in humans and livestock.

Recent studies have revisited the phage therapy as a biological alternative, which employs strictly lytic phages uncapable of lysogenization (Carter et al., 2012). Studies have demonstrated ability of phages to decrease biofilm formation in UPEC (Chibeu et al., 2012), increased mice rate survival in E. coli-induced pneumonia (Dufour et al., 2015). Moreover, lytic bacteriophages were used to infect and kill bacteria harboring phage-dependent conjugative plasmid to avoid emergence of multiresistant bacteria (Ojala et al., 2013; Tagliaferri et al., 2019). The phages cocktail EcoShield ${ }^{\mathrm{TM}}$ is already commercialized (Intralytix) and it has been reported to significantly reduce the E. coli O157:H7 contamination on surfaces and food (Abuladze et al., 2008; Carter et al., 2012). Additionally, mutual use of phages with antibiotics have emerged, with SPR02 and DAF6 phages combined with enrofloxacin have shown promising data, rescuing chickens challenged with avian pathogenic E. coli infection (Tagliaferri et al., 2019).

The novel approach via antivirulence-directed compounds works disarming the pathogens' ability to cause disease by inhibiting their virulence factors, favoring the host's immune defenses during the bacterial clearance. These compounds do not induce bacterial resistance as antibiotics, because they disarm the pathogen, instead of directly targeting its growth. Therefore, as they are directed to specific factors for pathogenesis, they potentially reduce the selection of resistance and limit collateral damage to the microbiota. Some virulence inhibitors are effective against many pathogens, molecules such as LED209, HC102A, HC103A, Artemisinin, and Ethoxzolamide, by inhibit different twocomponent systems as QseBC in E. coli and other enteropathogens (Sperandio et al., 2003; Rasko et al., 2008; Yang et al., 2014; Xue et al., 2015; Kim et al., 2020), Bicyclic 2pyridones, Biaryl mannoside, Nitazoxanide and FN075, avoiding the initial bacterial adhesion; and compounds like Toxtazins A and B, Ebselen, 7086, 7812, 7832, BPT15, and $\mathrm{BBH7}$, blocking toxins and secretion systems (Payne, 2008; Johnson and Abramovitch, 2017).

\section{CONCLUSION}

The forces that shape the evolution in E. coli comprise vast repertoire, affecting genetic flexibility and excessive permissiveness to acquire and donate DNA via horizontal gene 
transfer. These features guarantee the spread of antibiotic resistance as well as virulence factors inherited among the various pathotypes of $E$. coli. The exact identification and assessment assist researchers to better understand this bacterium modification, diagnosis, public health and treatment. E. coli strains with multiple and distinct factors are probably very common but unreported, since these E. coli strains have developed many strategies to persist in different settings and successfully infect the host. These strategies result in an immense variety of microorganisms, ranging from avirulent to extremely virulent strains that can cause intestinal or extraintestinal diseases. E. coli strains have great potential for dissemination and capacity to pass along hereditary elements. Currently, these HyPEC strains are a very concerning threat that demands more studies and the development of novel treatment methods.

\section{REFERENCES}

Abuladze, T., Li, M., Menetrez, M. Y., Dean, T., Senecal, A., and Sulakvelidze, A. (2008). Bacteriophages reduce experimental contamination of hard surfaces, tomato, spinach, broccoli, and ground beef by Escherichia coli O157:H7. Appl. Environ. Microbiol. 74, 6230-62 8. doi: 10.1128/AEM.01465-08.21

Ahmed, A., Li, J., Shiloach, Y., Robbins, J. B., and Szu, S. C. (2006). Safety and immunogenicity of Escherichia coli $\mathrm{O} 157 \mathrm{O}$-specific polysaccharide conjugate vaccine in 2-5-year-old children. J. Infect. Dis. 193, 515-521. doi: 10.1086/ 499821

Aslani, M. M., Alikhani, M. Y., Zavari, A., Yousefi, R., and Zamani, A. R. (2011). Characterization of enteroaggregative Escherichia coli (EAEC) clinical isolates and their antibiotic resistance pattern. Int. J. Infect. Dis. IJID Off. Publ. Intern. Soc Infec. Dis. 15 (2), e136-e139. doi: 10.1016/j.ijid.2010.10.002

Barrios-Villa, E., Cortés-Cortés, G., Lozano-Zaraín, P., Arenas-Hernández, M., Martínez de la Peña, C. F., Martínez-Laguna, Y., et al. (2018). Adherent/ invasive Escherichia coli (AIEC) isolates from asymptomatic people: new $E$. coli ST131 O25:H4/H30-Rx virotypes. Ann. Clin. Mic. Antim. 17 (1), 42. doi: 10.1186/s12941-018-0295-4

Baylis, C. L., Penn, C. W., Thielman, N. M., Guerrant, R. L., Jenkins, C., and Gillespie, S. H. (2006). "Escherichia coli and Shigella spp," in Principles and Practice of Clinical Bacteriology, 2nd ed. Eds. S. H. Gillespie and P. M. Hawkey (England, UK: John Wiley and Sons Ltd), 347-365. doi: 10.1002/ 9780470017968.ch28

Bielaszewska, M., Dobrindt, U., Gärtner, J., Gallitz, I., Hacker, J., Karch, J., et al. (2007). Aspects of genome plasticity in pathogenic Escherichia coli. Int. J. Med. Microbiol. 297 (7-8), 625-639. doi: 10.1016/j.ijmm.2007.03.001

Bielaszewska, M., Mellmann, A., Zhang, W., Köck, R., Fruth, A., Bauwens, A., et al. (2011). Characterisation of the Escherichia coli strain associated with an outbreak of haemolytic uraemic syndrome in German: a microbiological study. Lancet Infect. Dis. 11 (9), 671-676. doi: 10.1016/S1473-3099(11) 70165-7

Bielaszewska, M., Schiller, R., Lammers, L., Bauwens, A., Fruth, A., Middendorf, B., et al. (2014). Heteropathogenic virulence and phylogeny reveal phased pathogenic metamorphosis in Escherichia coli O2:H6. EMBO Mol. Med. 6, 347-357. doi: 10.1002/emmm.201303133

Biran, D., and Ron, E. Z. (2018). Extraintestinal Pathogenic Escherichia coli. Curr. Top. Microbiol. Immunol. 416, 149-161. doi: 10.1007/82_2018_108

Bitzan, M., Poole, R., Mehran, M., Sicard, E., Brockus, C., Thuning-Roberson, C., et al. (2009). Safety and pharmacokinetics of chimeric anti-Shiga toxin 1 and anti-Shiga toxin 2 monoclonal antibodies in healthy volunteers. Antimicrob. Agents Chemother. 53, 3081-3087. doi: 10.1128/AAC.01661-08

Boll, E. J., Overballe-Petersen, S., Hasman, H., Roer, L., Ng, K., Scheutz, F., et al. (2018). Emergence of enteroaggregativeEscherichia coli within the ST131

\section{AUTHOR CONTRIBUTIONS}

VB: writing and organization. KM: writing. CM: writing and mentoring. All authors contributed to the article and approved the submitted version.

\section{FUNDING}

Financially supported by FAPESP (grants 2014/06779-2, 2018/ 22412-2, 2018/22042-0, and 2019/03049-7), CNPq (307418/ 2017-0), and "Programa de Apoio ao Desenvolvimento Científico da Faculdade de Ciências Farmacêuticas da UNESPPADC. This study was financed in part by the Coordenação de Aperfeiçoamento de Pessoal de Nivel Superior - Brasil (CAPES) Finance Code 001.

lineage as a cause of extraintestinal infections. mBio 11 (3), e00353-e00420. doi: $10.1128 / \mathrm{mBio} .00353-20$

Brigulla, M., and Wackernagel, W. (2010). Molecular aspects of gene transfer and foreign DNA acquisition in prokaryotes with regard to safety issues. Appl. Microbiol. Biotechnol. 86 (4), 1027-1041. doi: 10.1007/s00253-010-2489-3

Brzuszkiewicz, E., Gottschalk, G., Ron, E., Hacker, J., and Dobrindt, U. (2009). Adaptation of Pathogenic E. coli to Various Niches: Genome Flexibility is the Key. Genome Dyn. 6, 110-125. doi: 10.1159/000235766

Cag, Y., Caskurlu, H., Fan, Y., Cao, B., and Vahaboglu, H. (2016). Resistance mechanisms. Ann. Transl. Med. 4 (17), 326. doi: 10.21037/atm.2016.09.14

Calderon Toledo, C., Arvidsson, I., and Karpman, D. (2011). Cross-reactive protection against enterohemorrhagic Escherichia coli infection by enteropathogenic E. coli in a mouse model. Infect. Immun. 79, 2224-2233. doi: 10.1128/IAI.01024-10

Carattoli, A. (2009). Resistance plasmid families in Enterobacteriaceae. Ant. Agents Chemother. 53 (6), 2227-2238. doi: 10.1128/AAC.01707-08

Carattoli, A. (2013). Plasmids and the spread of resistance. Int. J. Med. Microbiol. 303, 298-304. doi: 10.1016/j.ijmm.2013.02.001

Carter, C. D., Parks, A., Abuladze, T., Li, M., Woolston, J., Magnone, J., et al. (2012). Bacteriophage cocktail significantly reduces Escherichia coli O157: H7 contamination of lettuce and beef, but does not protect against recontamination. Bacteriophage 2 (3), 178-185. doi: 10.4161/bact.22825

Chahales, P., Hoffman, P. S., and Thanassi, D. G. (2016). Nitazoxanide Inhibits Pilus Biogenesis by Interfering with Folding of the Usher Protein in the Outer Membrane. Antimicrob. Agents Chemother. 60, 2028-2038. doi: 10.1128/ AAC.02221-15

Chattaway, M. A., Day, M., Mtwale, J., White, E., Rogers, J., Day, M., et al. (2017). Clonality, virulence and antimicrobial resistance of enteroaggregative Escherichia coli from Mirzapur, Bangladesh. J. Med. Microbiol. 66 (10), 1429-1435. doi: 10.1099/jmm.0.000594

Chibeu, A., Lingohr, E. J., Masson, L., Manges, A., Harel, J., Ackermann, H.-W., et al. (2012). Bacteriophages with the ability to degrade uropathogenic Escherichia coli biofilms. Viruses 4, 471-487. doi: 10.3390/v4040471

Curtis, M. M., Russell, R., Moreira, C. G., Adebesin, A. M., Wang, C., Williams, N. S., et al. (2014). QseC inhibitors as an antivirulence approach for Gramnegative pathogens. MBio 5 (6), e02165. doi: 10.1128/mBio.02165-14

Day, M., Doumith, M., Jenkins, C., Dallman, T. J., Hopkins, K. L., Elson, R., et al. (2017). Antimicrobial resistance in Shiga toxin-producing Escherichia coli serogroups $\mathrm{O} 157$ and $\mathrm{O} 26$ isolated from human cases of diarrhoeal disease in Englan. J. Antimicrob. Chemother. 72 (1), 145-152. doi: 10.1093/ $\mathrm{jac} / \mathrm{dkw} 371$

Dobrindt, U., Agerer, F., Michaelis, K., Janka, A., Buchrieser, C., Samuelson, M., et al. (2003). Analysis of genome plasticity in pathogenic and commensal Escherichia coli isolates by use of DNA arrays. J. Bacteriol. 185 (6), 1831-1840. doi: 10.1128/jb.185.6.1831-1840.2003 
Dobrindt, U., Chowdary, M. G., Krumbholz, G., and Hacker, J. (2010). Genome dynamics and its impact on evolution of Escherichia coli. Med. Microbiol. Immunol. 199 (3), 145-154. doi: 10.1007/s00430-010-0161-2

Ducarmon, Q. R., Zwittink, R. D., Hornung, B. V. H., van Schaik, W., Young, V. B., and Kuijper, E. J. (2019). Gut Microbiota and Colonization Resistance against Bacterial Enteric Infection. Microbiol. Mol. Biol. Rev. 83 (3), e00007-e00019. doi: 10.1128/MMBR.00007-19

Dufour, N., Debarbieux, L., Fromentin, M., and Ricard, J. D. (2015). Treatment of highly virulent extraintestinal pathogenic Escherichia coli pneumonia with bacteriophages. Crit. Care Med. 43 (6), e190-e198. doi: 10.1097/CCM. 0000000000000968

Dutta, S., Pazhani, G. P., Nataro, J. P., and Ramamurthy, T. (2015). Heterogenic virulence in a diarrheagenic Escherichia coli: evidence for an EPEC expressing heat-labile toxin of ETEC. Int. J. Med. Microbiol. 305, 47-54. doi: 10.1016/ j.ijmm.2014.10.006

Elbediwi, M., Li, Y., Paudyal, N., Pan, H., Li, X., Xie, S., et al. (2019). Global Burden of Colistin-Resistant Bacteria: Mobilized Colistin Resistance Genes Study, (1980-2018). Microorganisms 7 (10), E461. doi: 10.3390/microorganisms 7100461

Elliott, S. J., Srinivas, S., Albert, M. J., Alam, K., Robins-Browne, R. M., Gunzburg, S. T., et al. (1998). Characterization of the roles of hemolysin and other toxins in enteropathy caused by alpha-hemolytic Escherichia coli linked to human diarrhea. Infect. Immun. 66, 2040-2051. doi: 10.1128/IAI.66.5.2040-2051.1998

Fabich, A. J., Jones, S. A., Chowdhury, F. Z., Cernosek, A., Anderson, A., Smalley, D., et al. (2008). Comparison of carbon nutrition for pathogenic and commensal Escherichia coli strains in the mouse intestine. Infect. Immun. 76, 1143-1152. doi: 10.1128/IAI.01386-07

Fábrega, V. L. A., Ferreira, A. J. P., Patrício, F. R. S., Brinkley, C., and Scaletsky, I. C. A. (2002). Cell-detaching Escherichia coli(CDEC) strains from children with diarrhea: Identification of a protein with toxigenic activity. FEMS Microbiol. Lett. 217 (2), 191-197. doi: 10.1111/j.1574-6968.2002.tb11474.x

Fernandes, M. R., McCulloch, J. A., Vianello, M. A., Moura, Q., Perez-Chaparro, P. J., Esposito, F., et al. (2016). First Report of the Globally Disseminated IncX4 Plasmid Carrying the mcr-1 Gene in a Colistin-Resistant Escherichia coli Sequence Type 101 Isolate from a Human Infection in Brazil. Antimic. Agents Chemother. 60 (10), 6415-6417. doi: 10.1128/AAC.01325-16

Frost, L. S., Leplae, R., Summers, A. O., and Toussaint, A. (2005). Mobile genetic elements: the agents of open source evolution. Nat. Rev. Microbiol. 3 (9), $722-$ 732. doi: $10.1038 /$ nrmicrol 235

Gadde, U., Kim, W. H., Oh, S. T., and Lillehoj, H. S. (2017). Alternatives to antibiotics for maximizing growth performance and feed efficiency in poultry: a review. Anim. Health Res. Rev. 18 (1), 26-45. doi: 10.1017/S1466252316000207

García-Angulo, V. A., Kalita, A., Kalita, M., Lozano, L., and Torres, A. G. (2014). Comparative genomics and immunoinformatics approach for the identification of vaccine candidates for enterohemorrhagic Escherichia coli O157:H7. Infect. Immun. 82, 2016-2026. doi: 10.1128/IAI.01437-13

Garmendia, J., Frankel, G., and Crepin, V. F. (2005). Enteropathogenic and enterohemorrhagic Escherichia coli infections: translocation, translocation, translocation. Infect. Immun. 73 (5), 2573-2585. doi: 10.1128/IAI.73.5.25732585.2005

Gioia-Di Chiacchio, R. M., Cunha, M. P. V., de Sá, L. R. M., Davies, Y. M., Pereira, C. B. P., Martins, F. H., et al. (2018). Novel Hybrid of Typical Enteropathogenic Escherichia coli and Shiga-Toxin-Producing E. coli (tEPEC/STEC) Emerging From Pet Birds. Front. Microbiol. 9:2975:2975. doi: 10.3389/fmicb.2018.02975

Gomes, T. A., Elias, W. P., Scaletsky, I. C., Guth, B. E., Rodrigues, J. F., and Piazza, R. M. (2016). Diarrheagenic Escherichia coli. Braz. J. Microbiol. 47 Suppl 1, 330. doi: 10.1016/j.bjm.2016.10.015

Gunzburg, S. T., Chang, B. J., Elliott, S. J., Burke, V., and Gracey, M. (1993). Diffuse and enteroaggregative patterns of adherence of enteric Escherichia coli isolated from aboriginal children from the Kimberley region of Western Australia. J. Infect. Dis. 167, 755-758. doi: 10.1093/infdis/167.3.755

Hacker, J., Hentschel, U., and Dobrindt, U. (2003). Prokaryotic chromosomes and disease. Science 301 (5634), 790-793. doi: 10.1126/science.1086802

Hadjifrangiskou, M., Kostakioti, M., Chen, S. L., Henderson, J. P., Greene, S. E., and Hultgren, S. J. (2011). A central metabolic circuit controlled by QseC in pathogenic Escherichia coli. Mol. Microbiol. 80 (6), 1516-1529. doi: 10.1111/ j.1365-2958.2011.07660.x
Han, Z., Pinkner, J. S., Ford, B., Chorell, E., Crowley, J. M., Cusumano, C. K., et al. (2012). Lead optimization studies on FimH antagonists: discovery of potent and orally bioavailable ortho-substituted biphenyl mannosides. J. Med. Chem. 55, 3945-3959. doi: $10.1021 / \mathrm{jm} 300165 \mathrm{~m}$

Hazen, T. H., Michalski, J., Luo, Q., Shetty, A. C., Daugherty, S. C., Fleckenstein, J. M., et al. (2017). Comparative genomics and transcriptomics of Escherichia coli isolates carrying virulence factors of both enteropathogenic and enterotoxigenic E. coli. Sci. Rep. 7, 3513. doi: 10.1038/s41598-017-03489-z

Ingle, D. J., Levine, M. M., Kotloff, K. L., Holt, K. E., and Robins-Browne, R. M. (2018). Dynamics of antimicrobial resistance in intestinal Escherichia coli from children in community settings in South Asia and sub-Saharan Africa. Nat. Microbiol. 3 (9), 1063-1073. doi: 10.1038/s41564-018-0217-4

Jackson, R. W., Vinatzer, B., Arnold, D. L., Dorus, S., and Murillo, J. (2011). The influence of the accessory genome on bacterial pathogen evolution. Mob. Genet. Elements 1 (1), 55-65. doi: 10.4161/mge.1.1.16432

Jarvis, C., Han, Z., Kalas, V., Klein, R., Pinkner, J. S., Ford, B., et al. (2016). Antivirulence Isoquinolone Mannosides: Optimization of the Biaryl Aglycone for FimH Lectin Binding Affinity and Efficacy in the Treatment of Chronic UTI. ChemMedChem 11 (4), 367-373. doi: 10.1002/cmdc.201600006

Jerse, A. E., Yu, J., Tall, B. D., and Kaper, J. B. (1990). A genetic locus of enteropathogenic Escherichia coli necessary for the production of attaching and effacing lesions on tissue culture cells. Proc. Natl. Acad. Sci. U.S.A. 87 (20), 7839-7843. doi: 10.1073/pnas.87.20.7839

Johnson, B. K., and Abramovitch, R. B. (2017). Small Molecules That Sabotage Bacterial Virulence. Trends Pharmacol. Sci. 38 (4), 339-362. doi: 10.1016/ j.tips.2017.01.004

Johnson, J. R., and Russo, T. A. (2018). Molecular Epidemiology of Extraintestinal Pathogenic Escherichia coli. EcoSal. Plus 8 (1), 4-22. doi: 10.1128/ ecosalplus.ESP-0004-2017

Kaper, J. B., Nataro, J. P., and Mobley, H. L. (2004). Pathogenic Escherichia coli. Nat. Rev. Microbiol. 2 (2), 123-140. doi: 10.1038/nrmicro818

Khan, A., Miller, W. R., and Arias, C. A. (2018). Mechanisms of antimicrobial resistance among hospital-associated pathogens. Expert Rev. Anti. Infect. Ther. 16 (4), 269-287. doi: 10.1080/14787210.2018.1456919

Kim, C. S., Gatsios, A., Cuesta, S., Lam, Y. C., Wei, Z., Chen, H., et al. (2020). Characterization of Autoinducer-3 Structure and Biosynthesis in E. coli. ACS Cent. Sci. 6 (2), 197-206. doi: 10.1021/acscentsci.9b01076

Knutton, S., Baldwin, T., Williams, P. H., and McNeish, A. S. (1989). Actin accumulation at sites of bacterial adhesion to tissue culture cells: basis of a new diagnostic test for enteropathogenic and enterohemorrhagic Escherichia coli. Infect. Immun. 57 (4), 1290-1298. doi: 10.1128/IAI.57.4.1290-1298.1989

Köhler, C. D., and Dobrindt, U. (2011). What defines extraintestinal pathogenic Escherichia coli? Int. J. Med. Microbiol. 301 (8), 642-647. doi: 10.1016/ j.ijmm.2011.09.006

Korhonen, T. K., Valtonen, M. V., Parkkinen, J., Väisänen-Rhen, V., Finne, J., Orskov, F., et al. (1985). Serotypes, hemolysin production, and receptor recognition of Escherichia coli strains associated with neonatal sepsis and meningitis. Infect. Immun. 48 (2), 486-491. doi: 10.1128/IAI.48.2.486491.1985

Lindstedt, B. A., Finton, M. D., Porcellato, D., and Brandal, L. T. (2018). High frequency of hybrid Escherichia coli strains with combined Intestinal Pathogenic Escherichia coli(IPEC) and Extraintestinal Pathogenic Escherichia coli (ExPEC) virulence factors isolated from human faecal samples. BMC Infect. Dis. 18, 544. doi: 10.1186/s12879-018-3449-2

Liu, J., Sun, Y., Feng, S., Zhu, L., Guo, X., and Qi, C. (2009). Towards an attenuated enterohemorrhagic Escherichia coli $\mathrm{O} 157: \mathrm{H} 7$ vaccine characterized by a deleted ler gene and containing apathogenic Shiga toxins. Vaccine 27, 5929-5935. doi: 10.1016/j.vaccine.2009.07.097

Logue, C. M., Doetkott, C., Mangiamele, P., Wannemuehler, Y. M., Johnson, T. J., Tivendale, K. A., et al. (2012). Genotypic and phenotypic traits that distinguish neonatal meningitis-associated Escherichia coli from fecal E. coli isolates of healthy human hosts. Appl. Environ. Microbiol. 78 (16), 5824-5830. doi: 10.1128/AEM.07869-11

Lustri, B. C., Sperandio, V., and Moreira, C. G. (2017). Bacterial chat: intestinal metabolites and signals in host-microbiota-pathogen interactions. Infec. Immun. 85 (12), e00476. doi: 10.1128/IAI.00476-17

Maltby, R., Leatham-Jensen, M. P., Gibson, T., Cohen, P. S., and Conway, T. (2013). Nutritional basis for colonization resistance by human commensal 
Escherichia coli strains HS and Nissle 1917 against E. coli O157:H7 in the mouse intestine. PloS One 8, e53957. doi: 10.1371/journal.pone.0053957

Manning, S. D., Motiwala, A. S., Springman, A. C., Qi, W., Lacher, D. W., Ouellette, L. M., et al. (2008). Variation in virulence among clades of Escherichia coli O157:H7 associated with disease outbreaks. Proc. Natl. Acad. Sci. U.S.A. 105 (12), 4868-4873. doi: 10.1073/pnas.0710834105

Mariani-Kurkdjian, P., Lemaitre, C., Bidet, P., Perez, D., Boggini, L., Kwon, T., et al. (2014). Haemolytic-uraemic syndrome with bacteraemia caused by a new hybrid Escherichia coli pathotype. New Microbes New Infect. 2, 127-131. doi: $10.1002 / \mathrm{nmi} 2.49$

Marques, L. R., Abe, C. M., Grin, P. M., and Gomes, T. A. T. (1995). Association between alpha-hemolysin production and HeLa cell-detaching activity in fecal isolates of Escherichia coli. J. Clin. Microbiol. 33, 2707-2709. doi: 10.1128/ JCM.33.10.2707-2709.1995

McKenzie, R., Bourgeois, A. L., Frech, S. A., Flyer, D. C., Bloom, A., Kazempour, K., et al. (2007). Transcutaneous immunization with the heat-labile toxin (LT) of enterotoxigenic Escherichia coli (ETEC): protective efficacy in a double-blind, placebo-controlled challenge study. Vaccine 25, 3684-3691. doi: 10.1016/ j.vaccine.2007.01.043

Medina, A. M., Rivera, F. P., Pons, M. J., Riveros, M., Gomes, C., Bernal, M., et al. (2015). Comparative analysis of antimicrobial resistance in enterotoxigenic Escherichia coli isolates from two paediatric cohort studies in Lima, Peru. Trans. R. Soc Trop. Med. Hyg. 109 (8), 493-502. doi: 10.1093/trstmh/trv054

Mellies, J. L., Elliott, S. J., Sperandio, V., Donnenberg, M. S., and Kaper, J. B. (1999). The Per regulon of enteropathogenic Escherichia coli: identification of a regulatory cascade and a novel transcriptional activator, the locus of enterocyte effacement (LEE)-encoded regulator (Ler). Mol. Microbiol. 33 (2), 296-306. doi: 10.1046/j.1365-2958.1999.01473.x

Mobley, H., Donnenberg, M., and Hagan, E. (2009). Uropathogenic Escherichia coli, EcoSal Plus 2009. EcoSal Plus 3 (2), 1-27. doi: 10.1128/ecosalplus.8.6.1.3

Mokady, D., Gophna, U., and Ron, E. Z. (2005). Virulence factors of septicemic Escherichia coli strains. Int. J. Med. Microbiol. 295 (6-7), 455-462. doi: 10.1016/ j.ijmm.2005.07.007

Muniesa, M., Hammerl, J. A., Hertwig, S., Appel, B., and Brüssow, H. (2012). Shiga toxin-producing Escherichia coli O104: H4: a new challenge for microbiology. Appl. Environ. Microbiol. 78 (12), 4065-4073. doi: 10.1128/AEM.00217-12

Nagarjuna, D., Mittal, G., Dhanda, R. S., Gaind, R., and Yadav, M. (2018). Alarming levels of antimicrobial resistance among sepsis patients admitted to ICU in a tertiary care hospital in India - a case control retrospective study. Antimicrob. Resist. Infect. Control 7, 150. doi: 10.1186/s13756-018-0444-8

Nash, J. H., Villegas, A., Kropinski, A. M., Aguilar-Valenzuela, R., Konczy, P., Mascarenhas, M., et al. (2010). Genome sequence of adherent-invasive Escherichia coli and comparative genomic analysis with other E. coli pathotypes. BMC Genomics 11, 667. doi: 10.1186/1471-2164-11-667

Navarro-Garcia, F. (2014). Escherichia coli O104:H4 Pathogenesis: an EnteroaggregativeE.coli/Shiga Toxin-Producing E. coli Explosive Cocktail of HighVirulence. Microbiol. Spectr. 2 (6), 2-15. doi: 10.1128/microbiolspec. EHEC-0008-2013

Nesta, B., and Pizza, M. (2018). "Vaccines against Escherichia coli. "In Escherichia coli, a Versatile Pathogen (Cham: Springer), 213-242. doi: 10.1007/ 82_2018_111

Nyholm, O., Halkilahti, J., Wiklund, G., Okeke, U., Paulin, L., Auvinen, P., et al. (2015). Comparative genomics and characterization of hybrid Shigatoxigenic and Enterotoxigenic Escherichia coli (STEC/ETEC) strains. PloS One 10, e0135936. doi: 10.1371/journal.pone.0135936

Ogura, Y., Ooka, T., Iguchi, A., Toh, H., Asadulghani, M., Oshima, K., et al. (2009). Comparative genomics reveal the mechanism of the parallel evolution of O157 and non-O157 enterohemorrhagic Escherichia coli. Proc. Natl. Acad. Sci. U.S.A. 106 (42), 17939-17944. doi: 10.1073/pnas.0903585106

Ojala, V., Laitalainen, J., and Jalasvuori, M. (2013). Fight evolution with evolution: plasmid-dependent phages with a wide host range prevent the spread of antibiotic resistance. Evol. Appl. 6, 925-932. doi: 10.1111/eva.12076

Okeke, I. N., Steinrück, H., Kanack, K. J., Elliott, S. J., Sundström, L., Kaper, J. B., et al. (2002). Antibiotic-resistant cell-detaching Escherichia coli strains from Nigerian children. J. Clin. Microb. 40 (1), 301-305. doi: 10.1128/jcm.40.1.301305.2002

Oliveira, A. F., Cardoso, S. A., Almeida, F. B., de Oliveira, L. L., Pitondo-Silva, A., Soares, S. G., et al. (2012). Oral immunization with attenuated Salmonella vaccine expressing Escherichia coli O157:H7 intimin gamma triggers both systemic and mucosal humoral immunity in mice. Microbiol. Immunol. 56, 513-522. doi: 10.1111/j.1348-0421.2012.00477.x

Pawłowska, B., and Sobieszczańska, B. M. (2017). Intestinal epithelial barrier: The target for pathogenic Escherichia coli. Adv. Clin. Exp. Med. 26 (9), 1437-1445. doi: $10.17219 /$ acem/64883

Payne, D. J. (2008). Microbiology. Desperately seeking new antibiotics. Science 321 (5896), 1644-1645. doi: 10.1126/science.1164586

Peigne, C., Bidet, P., Mahjoub-Messai, F., Plainvert, C., Barbe, V., Médigue, C., et al. (2009). The plasmid of Escherichia coli strain S88 (O45:K1:H7) that causes neonatal meningitis is closely related to avian pathogenic E. coli plasmids and is associated with high-level bacteremia in a neonatal rat meningitis model. Infect. Immune 77 (6), 2272-2284. doi: 10.1128/IAI.01333-08

Petty, N. K., Ben Zakour, N. L., Stanton-Cook, M., Skippington, E., Totsika, M., Forde, B. M., et al. (2014). Global dissemination of a multidrug resistant Escherichia coli clone. Proc. Nat. Acad. Sci. U.S.A. 111 (15), 5694-5699. doi: 10.1073/ pnas.1322678111

Pinkner, J. S., Remaut, H., Buelens, F., Miller, E., Aberg, V., Pemberton, N., et al. (2006). Rationally designed small compounds inhibit pilus biogenesis in uropathogenic bacteria. Proc. Natl. Acad. Sci. U.S.A. 103, 17897-17902. doi: $10.1073 /$ pnas.0606795103

Rakitina, D. V., Manolov, A. I., Kanygina, A. V., Garushyants, S. K., Baikova, J. P., Alexeev, D. G., et al. (2017). Genome analysis of E. coli isolated from Crohn's disease patients. BMC Genomics 18 (1), 544. doi: 10.1186/s12864-017-3917-x

Rasko, D. A., Moreira, C. G., de Li, R., Reading, N. C., Ritchie, J. M., Waldor, M. K., et al. (2008). Targeting QseC signaling and virulence for antibiotic development. Science 321 (5892), 1078-1080. doi: 10.1126/science.1160354

Rasko, D. A., Webster, D. R., Sahl, J. W., Bashir, A., Boisen, N., Scheutz, F., et al. (2011). Origins of the E. coli strain causing an outbreak of hemolytic-uremic syndrome in Germany. N Engl. J. Med. 365 (8), 709-717. doi: 10.1056/NEJMoa1 106920

Regua-Mangia, A. H., Gomes, T. A., Vieira, M. A., Irino, K., and Teixeira, L. M. (2009). Molecular typing and virulence of enteroaggregative Escherichia coli strains isolated from children with and without diarrhoea in Rio de Janeiro city, Brazil. J. Med. Microbiol. 58, 414-422. doi: 10.1099/jmm.0.006502-0

Ribeiro, T. R. M., Lustri, B. C., Elias, W. P., and Moreira, C. G. (2019). QseC Signaling in the Outbreak O104:H4 Escherichia coli Strain Combines Multiple Factors during Infection. J. Bacteriol. Aug. 8, e00203-e00219, 201(17). doi: 10.1128/JB.00203-19

Rodríguez-Martínez, J. M., Machuca, J., Cano, M. E., Calvo, J., Martínez-Martínez, L., and Pascual, A. (2016). Plasmid-mediated quinolone resistance: two decades on. Drug Resist. Update 29, 13-29. doi: 10.1016/j.drup.2016.09.001

Rojas-Lopez, M., Monterio, R., Pizza, M., Desvaux, M., and Rosini, R. (2018). Intestinal pathogenic Escherichia coli: insights for vaccine development. Front. Microbiol. 9, 440. doi: 10.3389/fmicb.2018.00440

Rooks, M. G., Veiga, P., Reeves, A. Z., Lavoie, S., Yasuda, K., Asano, Y., et al. (2017). QseC inhibition as an antivirulence approach for colitis-associated bacteria. Proc. Natl. Acad. Sci. U.S.A. 114 (1), 142-147. doi: 10.1073/pnas.1612836114

Sadeyen, J.-R., Wu, Z., Davies, H., van Diemen, P. M., Milicic, A., La Ragione, R. M., et al. (2015). Immune responses associated with homologous protection conferred by commercial vaccines for control of avian pathogenic Escherichia coli in turkeys. Vet. Res. 461), 5. doi: 10.1186/s13567-014-0132-5

Santos, A. C. M., Santos, F. F., Silva, R. M., and Gomes, T. A. T. (2020). Diversity of Hybrid- and Hetero-Pathogenic Escherichia coli and Their Potential Implication in More Severe Diseases. Front. Cell. Infect. Microbiol. 10, 339. doi: $10.3389 /$ fcimb.2020.00339

Servin, A. L. (2014). Pathogenesis of human diffusely adhering Escherichia coli expressing Afa/Dr adhesins (Afa/Dr DAEC): current insights and future challenges. Clin. Mic. Rev. 27 (4), 823-869. doi: 10.1128/CMR.00036-14

Shamir, E. R., Warthan, M., Brown, S. P., Nataro, J. P., Guerrant, R. L., and Hoffman, P. S. (2010). Nitazoxanide inhibits biofilm production and hemagglutination by enteroaggregative Escherichia coli strains by blocking assembly of AafA fimbriae. Antimicrob. Agents Chemother. 54, 1526-1533. doi: 10.1128/AAC.01279-09

Sheppard, S. K., Guttman, D. S., and Fitzgerald, J. R. (2018). Population genomics of bacterial host adaptation. Nat. Rev. Genet. 19 (9), 549-565. doi: 10.1038/s41576018-0032-z

Sperandio, V., Torres, A. G., Jarvis, B., Nataro, J. P., and Kaper, J. B. (2003). Bacteria-host communication: the language of hormones. PNAS 22100 (15), 8951-8956. doi: 10.1073/pnas.1537100100 
Tagliaferri, T. L., Mathias, J., and Hans-Peter, H. (2019). Fighting pathogenic bacteria on two fronts: phages and antibiotics as combined strategy. Front. Cel. Infect. Microb. 9, 22. doi: 10.3389/fcimb.2019.00022

Tobe, T., Hayashi, T., Han, C. G., Schoolnik, G. K., Ohtsubo, E., and Sasakawa, C. (1999). Complete DNA sequence and structural analysis of the enteropathogenic Escherichia coli adherence factor plasmid. Infect. Immun. 67 (10), 5455-5462. doi: 10.1128/IAI.67.10.5455-5462.1999

Touchon, M., Hoede, C., Tenaillon, O., Barbe, V., Baeriswyl, S., Bidet, P., et al. (2009). Organised genome dynamics in the Escherichia coli species results in highly diverse adaptive paths. PloS Genet. 5 (1), e1000344. doi: 10.1371/ journal.pgen.1000344

Trabulsi, L. R., Keller, R., and Tardelli Gomes, T. A. (2002). Typical and atypical enteropathogenic Escherichia coli. Emerg. Infect. Dis. 8 (5), 508-513. doi: 10.3201/eid0805.010385

van den Dobbelsteen, G., Fae, K. C., Serroyen, J., van den Nieuwenhof, I. M., Braun, M., Haeuptle, M. A., et al. (2016). Immunogenicity and safety of a tetravalent $E$. coli $\mathrm{O}$-antigen bioconjugate vaccine in animal models. Vaccine 34, 4152e60. doi: 10.1016/j.vaccine.2016.06.067

World Health Organization. (2018). Global antimicrobial resistance surveillance system (GLASS) report. Early implemetantion 2016-2017, ISBN: .

Xue, X. Y., Mao, X. G., Li, Z., Chen, Z., Zhou, Y., Hou, Z., et al. (2015). A potent and selective antimicrobial poly(amidoamine) dendrimer conjugate with LED209 targeting QseC receptor to inhibit the virulence genes of gramnegative bacteria. Nanomedicine 11 (2), 329-339. doi: 10.1016/j.nano.2014. 09.016
Yang, Q., Anh, N. D., Bossier, P., and Defoirdt, T. (2014). Norepinephrine and dopamine increase motility, biofilm formation, and virulence of Vibrio harveyi. Front. Microbiol. 5:584:584. doi: 10.3389/fmicb.2014.00584

Zhang, X. H., He, K. W., Zhang, S. X., Lu, W. C., Zhao, P. D., Luan, X. T., et al. (2011). Subcutaneous and intranasal immunization with Stx2B-Tir-Stx1B-Zot reduces colonization and shedding of Escherichia coli O157:H7 in mice. Vaccine 29, 3923-3929. doi: 10.1016/j.vaccine.2011.02.007

Zheng, B., Dong, H., Xu, H., Lv, J., Zhang, J., Jiang, X., et al. (2016). Coexistence of MCR-1 and NDM-1 in Clinical Escherichia coli Isolates. Clin. Infect. Dis. 63 (10), 1393-1395. doi: 10.1093/cid/ciw553

Zhong, L. L., Zhang, Y. F., Doi, Y., Huang, X., Zhang, X. F., Zeng, K. J., et al. (2017). Coproduction of MCR-1 and NDM-1 by Colistin-Resistant Escherichia coli Isolated from a Healthy Individual. Antimicrob. Agents Chemother. 61 (1), e01962-e01916. doi: 10.1128/AAC.01962-16

Conflict of Interest: The authors declare that the research was conducted in the absence of any commercial or financial relationships that could be construed as a potential conflict of interest.

Copyright (C) 2020 Braz, Melchior and Moreira. This is an open-access article distributed under the terms of the Creative Commons Attribution License (CC BY). The use, distribution or reproduction in other forums is permitted, provided the original author(s) and the copyright owner(s) are credited and that the original publication in this journal is cited, in accordance with accepted academic practice. No use, distribution or reproduction is permitted which does not comply with these terms. 